\title{
Physico-chemical, thermal and rheological characteristics of starch isolated from four commercial potatoes cultivars
}

\author{
J.A. Sanchez-González ${ }^{1}$; C. Echeverria1; L. Lescano ${ }^{1}$ iD; G. Linares ${ }^{1}$ iD; H.L.

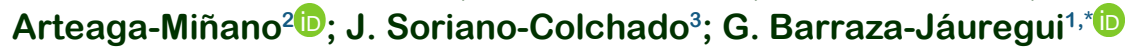 \\ Escuela de Ingeniería Agroindustrial, Facultad de Ciencias Agropecuarias, Universidad Nacional de Trujillo, \\ Trujillo, Perú. \\ 2 Applied and Computational Physic Laboratory, Faculty of Animal Science and Food Engineering, University of São \\ Paulo (USP), Pirassununga-SP, Brazil. \\ 3 Escuela de Ingeniería en Industrias Alimentarias, Facultad de Ciencias Agrarias, Universidad Privada Antenor \\ Orrego, Trujillo, Perú.
}

Received November 20, 2018. Accepted February 15, 2019.

\begin{abstract}
The physical-chemical, thermal and rheological properties of starches isolated from four commercial potato cultivars (Colparina, Huayro, Canchan and Yungay) were evaluated and characterized. The starches presented ovoid and spherical shapes, with average size from $20.08 \pm 2.48$ to $25.33 \pm 6.54 \mu \mathrm{m}$ and B-type granules, with amylose content from $15.49 \pm 2.02$ to $32.10 \pm 0.14 \%$ and relative crystallinity, between 34.6 and $37.3 \%$. The rheological properties measured using a dynamic rheometer, showed predominance storage module (G') on the loss module (G') during the frequency range $(0.01-3.20 \mathrm{~Hz})$ studied, which would classify them as weak gels. The starches presented low syneresis, high clarity, pasting temperature from $65.70 \pm 0.31^{\circ} \mathrm{C}$ to $67.70 \pm 0.23^{\circ} \mathrm{C}$, gelatinization start temperature (To); peak temperature (Tp); gelatinization final temperature (Tf) and gelatinization enthalpy $(\Delta H)$ values between $57.90 \pm 0.24$ and $62.23 \pm 0.17^{\circ} \mathrm{C} ; 61.18 \pm 0.01$ and $64.85 \pm 0.01{ }^{\circ} \mathrm{C} ; 65.5 \pm 0.31$ and $68.34 \pm 0.29{ }^{\circ} \mathrm{C}$; $11.49 \pm 0.8$ and $15.43 \pm 0.51 \mathrm{~J} / \mathrm{g}$, respectively. The starches evaluated had suitable properties to be used as ingredients in specific foods to improve their textural characteristics.
\end{abstract}

Keywords: Potatoes starch; amylose content; gelatinization; crystallinity; pasting; viscoelastic.

\section{Introduction}

Potato is the third most important food crop in the world after wheat and rice, with a total world production that surpasses $\mathbf{3 0 0}$ million tons (CIP, 2018); in Peru, La Libertad, currently the fourth place in the national production with 407880 t potatoes; 18475 ha of crops and an average yield of $17874 \mathrm{~kg} / \mathrm{ha}$. In this condition it surpassed and displaced the department of Junín to fifth place (INEI, 2017). Potato is a good source of starch $(70-80 \%$ d.b.) (Grommers and van der Krogt, 2009), being recognized its wide application of starches in the food and non-food industry. Knowing their functional properties and structural characteristics, such as gelatinization, retrogradation, solubility, swelling power, water retention capacity, rheological behavior and pasting properties is very desirable (Jiang et al., 2012). These properties are correlated with the morphology of the granule, amylose content, botanical source, among others (Wang et al., 2010).

The rheological properties of starch pastes determine its possible application as a thickening or gelling agent. The basic rheological characteristic of the starch paste is the viscosity, which changes according to the applied shear stress. The description of these changes as a function of the shear rate requires knowledge of the basic rheological power law state equations like Herschel-Bulkley or Ostwald-de Waele (Berski et al., 2011).

On the other hand, when the starch is heated in excess water, at high concentration, it swells irreversibly and gelatinizes in a characteristic temperature range. Therefore, a three-dimensional gel network that delays the separation of

How to cite this article:

Sanchez-González, J.A.; Echeverria, C.; Lescano, L.; Linares, H.L.; Arteaga-Miñano, H.L.; Soriano-Colchado, J.; Barraza-

Jáuregui, G. 2019. Optimización de las características nutricionales, texturales y sensoriales de cookies enriquecidas con chía (Salvia hispánica) y aceite extraído de tarwi (Lupinus mutabilis). Scientia Agropecuaria 10(1): 63-71. 
phases is formed, which provides a basic structure of food products such as bread, cakes and desserts (Joshi et al., 2013).

There are numerous differences between the physic-chemical and thermal properties of potato starches obtained from different varieties and multiple food systems. Therefore, the results of this research are essential to predict its functionality and its subsequent application in food.

\section{Materials and methods}

\subsection{Raw material}

The native starches were obtained from potatoes (Solanum tuberosum L.) purchased from Otuzco, La Libertad, Peru.

All the chemicals were analytical-grade quality and used without further purification.

\subsection{Methods}

\section{Starch extraction}

Potato starch was prepared as described by Liu et al. (2003) with some modifications. The potatoes were selected, classified (average weight 130-150 g), washed, peeled, cut and crushed in a semi-industrial blender with a ratio water-potato (2:1). Sodium bisulfite $(0.075 \% \mathrm{w} / \mathrm{v})$ was used in order to inhibit the enzymatic browning. Subsequently, the suspension was filtered through a sieve with $100 \mu \mathrm{m}$ mesh aperture to remove the fiber, and starch slurry was left at rest for 3 hours for starch settling. Then, the water was removed and the settled starch was placed in stainless steel trays, $0.5 \mathrm{~cm}$ thick and dried in a forced air oven (Memmert, UF 260plus, Germany) at $37^{\circ} \mathrm{C}$, to avoid modification of the starch to 8\% moisture. Dry starch was ground using a mortar and pestle to reduce particle size, screened with a $100 \mu \mathrm{m}$ mesh and packed in $0.25 \mathrm{~kg}$ polyethylene bags of $100 \mu \mathrm{m}$ thickness. Starch samples were stored at room temperature, until further evaluation.

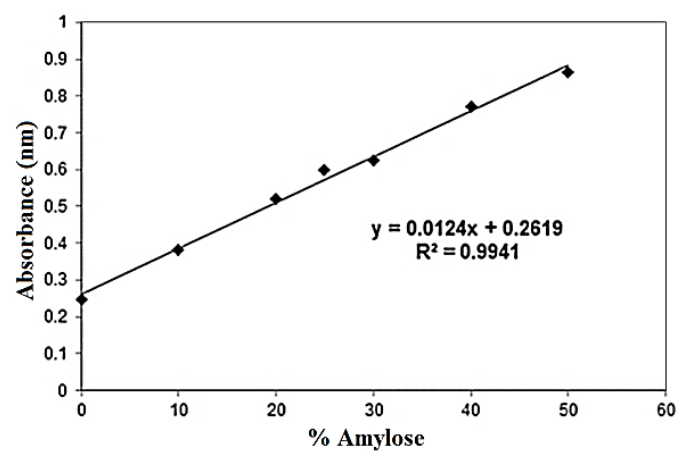

Figure 1. Standard curve for the determination of percentage of amylose and amylopectin in four varieties of Solanum tuberosum.

\section{Amylose and amylopectin content}

The amylose content was determined according to ISO 6647 methodology, with a change in the weight of the sample from $150 \mathrm{~g}$ to $10 \mathrm{~g}$. The standard curve for the determination of percentage of amylose and amylopectin in four varieties of Solanum tuberosum, is shown in Figure 1. Amylopectin content was calculated by $100 \%$ difference of the amylose content (Aristizábal et al., 2007).

\section{Syneresis}

The methodology of Singh et al. (2006) was used. Dispersions of $2 \%$ starch (dry base) were prepared with distilled water and heated at $90{ }^{\circ} \mathrm{C}$ for $30 \mathrm{~min}$ in a water bath with stirring (GFL, 1083, Germany); then cooled rapidly to $25^{\circ} \mathrm{C}$ (in $6 \mathrm{~min}$ ) using a bath with crushed ice. Samples were stored for 21 days at $4^{\circ} \mathrm{C}$. Syneresis was determined at day 7,15 and 21 days and the amount of water released (expressed as a percentage of the sample mass) after the sample centrifugation (Centrifuge NÜVE, NF400, Turkey) at 3000 rpm for $15 \mathrm{~min}$.

\section{Clarity}

Starch suspensions (1\%) were prepared with deionized water, placed in capped test tubes and heated at $100{ }^{\circ} \mathrm{C}$ for $30 \mathrm{~min}$, shaking them manually every $5 \mathrm{~min}$. Then, the tubes were cooled to $25^{\circ} \mathrm{C}$, using a bath with crushed ice. The gels were transferred to the $1 \mathrm{~cm}$ cell to determine values of clarity (measured as percentage of transmittance, $\% \mathrm{~T}$ ), using the spectrophotometer (UNICO ${ }^{\circ}, \quad$ UV-2100, United States) at $650 \mathrm{~nm}$, previously adjusted to zero with deionized water (Martínez et al., 2015).

\section{Morphological study - Scanning Electron Microscopy (SEM)}

The morphology of potato starch granules was observed by a scanning electron microscope (SEM) (Tescan, Vega 3 LMU, Czech Republic) using a secondary electron detector and a voltage of $30 \mathrm{KV}$. The samples were adhered on a doublesided carbon tape and coated with a gold layer of $0.150 \mathrm{~nm}$ by plasma deposition (PVD) using a DC Sputtering-SPI. By X-ray dispersive energy (EDS) and a Rx Quantax 200-Bruker detector, some elements present in the starch were identified, randomly selected areas were observed.

\section{Crystallinity $X$-ray diffraction}

Diffraction patterns were obtained using an X-ray Diffractometer (Bruker, ADVANCE ECO, Germany), with a CuKa source $(\lambda=$ $1.5405 \AA$ ) applying a voltage of $40.0 \mathrm{KV}$ and 
a current of $25.0 \mathrm{~mA}$. The analysis was performed at room temperature with sweeps in the $2 \theta$ range from $5^{\circ}$ to $60^{\circ}$ with a step size of $0.02^{\circ}$. The phases were identified using the database of PDF 2 of the ICCD (International Center for Diffraction Data). The crystallinity index was calculated using the TOPAS software ( $\mathrm{Li}$ et al., 2017).

\section{Thermal properties}

The methodology described by Lin et al. (2013) was used with slight modifications. The thermal gelatinization properties of starch were determined by the use of a differential scanning microcalorimeter (MCDSC, TA Instruments, USA). Starch sample (approximately $20 \mathrm{mg}$ ) was weighed into the capsule and distilled water (starch: water = 1:3) was added, then sealed and equilibrated at room temperature for $1 \mathrm{~h}$. The samples were heated from $25^{\circ} \mathrm{C}$ to 115 ${ }^{\circ} \mathrm{C}$ at a heating rate of $2{ }^{\circ} \mathrm{C} / \mathrm{min}$. Gelatinization enthalpy $(\Delta H)$ was calculated by integrating the area between the endothermic curve and a baseline under peak with NanoAnalyze software (TA instruments, New Castle, DE, USA) and expressed in terms of Joules per dry starch gram. Before measuring thermal properties, the equipment was calibrated performing an assay with ultrapure water samples, which validated correct functioning of the equipment.

\section{Rheological properties - Dynamic measures of viscoelasticity}

Dynamic viscoelasticity measurements were performed with the Thermo Haake (Haake, RS-150, USA) controlled stress rheometer, using the $60 \mathrm{~mm}$ dish-plate geometry (PP60) at a controlled temperature of $25^{\circ} \mathrm{C}$. Starch suspensions $(4 \% \mathrm{w} / \mathrm{w})$ were prepared, which were heated in a shaking water bath (GFL, model 1083, Germany) with controlled temperature at $90^{\circ} \mathrm{C}$ for 30 minutes. Then the gels were cooled to 25 ${ }^{\circ} \mathrm{C}$. The dynamic tests were carried out to characterize the viscoelastic behavior of starch gels, applying an oscillatory test. First, the effort sweep test $(0.1$ - $100 \mathrm{~Pa})$ was performed to determine the range of linear viscoelasticity at a constant frequency $(1 \mathrm{~Hz})$. Sample was allowed to rest in the rheometer for $10 \mathrm{~min}$ before starting the frequency sweep test. This test was performed at a constant deformation (1 $\mathrm{Pa}$ ) and in the range of $0.1-10 \mathrm{~Hz}$. Thus, the dynamic rheological parameters: storage modulus (G'), loss modulus (G') were determined as a function of oscillatory frequency, which was evaluated in triplicate (Martínez et al., 2015).

\section{Pasting properties}

Pasting properties of potato starches were determined with a Rapid Visco Analyzer (RVA-4, Newport Scientific, Warriewood, Australia). Each starch suspension (3 g, $14 \%$ d.b., $28 \mathrm{~g}$ total weight) was held at 50 ${ }^{\circ} \mathrm{C}$ for $1 \mathrm{~min}$, heated to $95^{\circ} \mathrm{C}$ in $3.7 \mathrm{~min}$, held at $95^{\circ} \mathrm{C}$ for $2.5 \mathrm{~min}$ and held at $50{ }^{\circ} \mathrm{C}$ for 2 min. Paddle speed was set at $960 \mathrm{rpm}$ for the first $10 \mathrm{~s}$ and then $160 \mathrm{rpm}$ for the rest of the analysis (Chang et al., 2006). Parameters such as pasting temperature (PT), peak viscosity (PV), hot paste viscosity (HV), and final viscosity (FV) were recorded, and the breakdown viscosity (BV = PV $\mathrm{HV}$ ) and setback viscosity (SV = FV - HV) were also calculated (Kaur et al., 2007).

\section{Statistical Analyses}

All analyzes were performed by triplicate, with individual preparation as it has been described in each method of analysis. The data was expressed as mean \pm standard deviation. The analysis of variance was used to calculate the significant differences and the test was used of discrimination of multiple differences of Fisher, using $p<0.05$ as the level of significance.

\section{Results and discussion}

\section{Morphological study - Scanning Electron Microscopy (SEM)}

As shown in Figure 2 (A, B, C, D), the images shown circular shapes for small sizes and elliptical for large sizes, with smooth and homogeneous surfaces, as reported by Medina and Salas (2008). In Figure 2B (Yungay) and 2D (Huayro), a greater quantity of granules with an irregular surface is observed, maybe corresponding to a higher amylose content (Table 1), as indicated (Gomand et al., 2010).

Table 1

Amylose and amylopectin content, and transmittance of potato starches

\begin{tabular}{lccc}
\hline Variety & $\begin{array}{c}\text { Amylose } \\
(\%)\end{array}$ & $\begin{array}{c}\text { Amylopectin } \\
(\%)\end{array}$ & $\begin{array}{c}\text { Transmittance } \\
(\%)\end{array}$ \\
\hline Colparina & $25.00 \pm 1.39 \mathrm{a}$ & $74.99 \pm 1.39 \mathrm{a}$ & $91.82 \pm 6.67 \mathrm{a}$ \\
Canchán & $15.49 \pm 2.02 \mathrm{a}$ & $84.50 \pm 2.02 \mathrm{a}$ & $87.56 \pm 7.11 \mathrm{ab}$ \\
Huayro & $32.10 \pm 0.14 \mathrm{~b}$ & $67.89 \pm 0.14 \mathrm{~b}$ & $64.24 \pm 3.60 \mathrm{~b}$ \\
Yungay & $26.67 \pm 6.37 \mathrm{ab}$ & $73.32 \pm 6.37 \mathrm{ab}$ & $78.39 \pm 4.89 \mathrm{ab}$ \\
\hline
\end{tabular}

Results are expressed as mean values \pm standard deviation of three determinations.

Different letters in the same column indicate significant difference $(p<0.05)$. 
Potato starch diameters were $20.08 \pm 2.48$, $22.36 \pm 8.22,21.42 \pm 5.51$ and $25.33 \pm 6.54$ $\mu \mathrm{m}$ for the variety Yungay, Canchan Huayro and Colparina, respectively. No statistical difference $(p>0.05)$ among the varieties was found. These values are within the range $(14$ to $50 \mu \mathrm{m})$ reported by Kaur et al. (2009) and Šimková et al. (2013) for potato starch granules. On the other hand, Canchan, Colparina and Huayro showed the greatest variability in granule size, whereas the Yungay variety showed more homogeneous granules. Morphological differences between potato starches are greater than between crops of any other botanical source, depending on agricultural practices (Singh et al., 2006).

\section{Amylose and Amylopectin content}

Amylose content showed significant differences $(p<0.05$ ) among the four potato varieties varying between $15.49 \pm 2.02$ and $32.10 \pm 0.14 \%$ (Table 1$)$. These values are in accordance to reported ranges by Singh et al. (2006) $(24.5 \%-27.5 \%)$ in native starch from four New Zealand potato cultivars; for starches from different India potato cultivars (15.0\% - 30.4\%) (Kaur et al., 2007); in starches from sixteen Czech Republic potato cultivars (18.79\% - 22.95\%) (Šimková et al., 2013). The variability in amylose and amylopectin ratio within different potato cultivars may be due to different factors, such as genotype, environmental conditions and cultural practice (Noda et al., 2004).

\section{Clarity}

Clarity is a key parameter to determine the application of starches in food products because they can give brilliance or opacity to final product (Torruco-Uco and Betancur-Ancona, 2007). Starch gels presented values of clarity (measured as percentage of transmittance) between $64.24 \pm 3.60 \%$ and $91.82 \pm 6.67 \%$ (Table 1 ), finding the highest value for potato starch pastes in varieties Colparina and Canchan. These results are similar to those reported by Martínez et al. (2015) (82.3 $00.32-94.1 \pm$ $0.72 \%$ ) who studied the transmittance (\%) of the starches of different native potatoes (Solanum phureja). Novelo-Cen and Betancur-Ancona (2005) mention that starches that have a lower amount of amylose are easily dispersed, which increases their clarity, as well as those with greater swelling power. This explains the results for Canchan, Huayro and Yungay, with a correlation of $90.11 \%$, since they presented greater clarity, with a lower content of amylose and smaller granule size.

\section{Syneresis}

From the results, significant differences were observed $(p<0.05)$ in potato starches syneresis, during storage at $4^{\circ} \mathrm{C}$. Figure $2 \mathrm{~A}$ shows that the syneresis of native starch gels increased progressively with the storage days. The lowest values of syneresis were presented by starches of varieties Colparina (6.62 $\pm 0.16 \%)$ and Yungay (2.83 $\pm 3.45 \%$ ) on day 7 of storage.

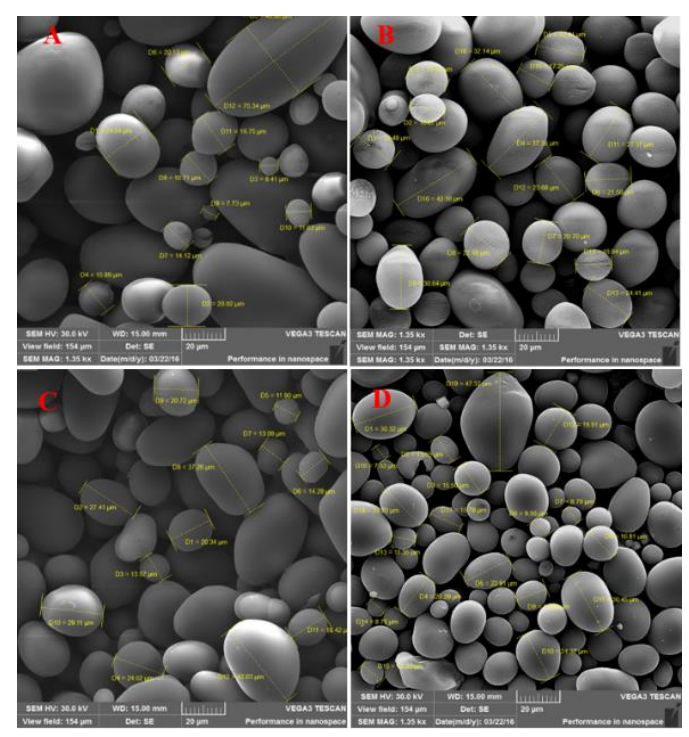

Figure 2. Scanning electron microscopy images of the potatoes starches granules: Canchan (A), Yungay (B), Colparina (C) and Huayro (D).

These results are similar to those reported by Martínez et al. (2015), who studied starches syneresis of nine native potatoes during 7 days of storage at $4{ }^{\circ} \mathrm{C}$, being the variety Combe $(3.8 \%)$ and Yana Churos $(4.6 \%)$ the lowest values of syneresis. According to these results, Canchan and Huayro potato starches can be used for food stored at low temperatures, which need some moisture exudation to provide a fresh appearance, such as puddings or sauces. On the other hand, Colparina and Yungay potato starches, due to their low syneresis, can be used in foods such as cake fillings, baby foods and soups (Hernández-Medina et al., 2008).

\section{Crystallinity $X$-ray diffraction}

All starches showed a type B crystallinity pattern, typical of potato starch (Zhou et al., 2016), showing characteristic peaks at reflection angles $(2 \theta)$ of $5.69^{\circ}$, a single peak at $17.20^{\circ}$ and a double at $22.33^{\circ}$ and $24.08^{\circ}$ (Figure 3 ), similar to those found by Chung et al. (2014) on starches of different potato varieties. 


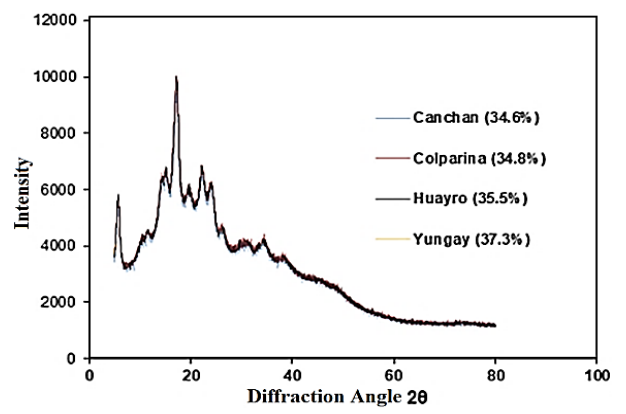

Figure 3. X-ray diffraction pattern of potato starches. Number in parenthesis indicates relative crystallinity.

The relative crystallinity, were $34.6 \%$, $34.8 \%, 35.5 \%$ and $37.3 \%$ for Canchan, Colparina, Huayro and Yungay potatoes varieties respectively, and was different for each variety. In the same way as Chung et al. (2014), who found for starches of different potato varieties, grown in two different places, relative crystallinity values from $34.2 \%$ to $37.9 \%$. The crystallinity of the starch granules is influenced by the structure of the amylopectin chain and the amylose content, with amylopectin being considered responsible for the crystallinity of the starch, while amylose interrupts its crystalline packing (Cheetham and Tao 1998). In the present study, only for the Huayro and Yungay varieties, the amylose content (Table 1) showed a negative correlation with the relative crystallinity. Consequently, the genetic differences between the four varieties of potato and culture conditions could be responsible for the differences in their amylose and amylopectin contents, which would originate the formation of a crystalline structure with different crystallinity (Chung et al., 2014).

\section{Thermal properties}

The temperature of gelatinization is an important parameter in the characterization of starch, and is defined as the temperature, at which the aqueous suspension of starch granules, subjected to heating, causes a collapse of the crystalline order within the starch, manifesting itself as ireversible changes in its properties (swelling of granules, sticking, loss of birefringence, unwinding and dissociation of double helices and solubility of starch) (Singh et al., 2003). Table 2 shows the parameters obtained by differential scanning calorimetry (DSC) for starch extracted from Canchan, Colparina, Huayro and Yungay potatoes varieties: gelatinization starts temperature (To); gelatinization peak temperature (Tp); gelatinization final temperature (Tf) and gelatinization enthalpy $(\Delta \mathrm{H})$, whose values were between $57.90 \pm 0.24$ and $62.23 \pm 0.17$ ${ }^{\circ} \mathrm{C}$; $61.18 \pm 0.01$ and $64.85 \pm 0.01{ }^{\circ} \mathrm{C}$; $65.5 \pm$ 0.31 and $68.34 \pm 0.29^{\circ} \mathrm{C} ; 11.49 \pm 0.8$ y 15.43 $\pm 0.51 \mathrm{~J} / \mathrm{g}$; respectively. These parameters were lower than those reported by Hernández-Medina et al. (2008) for potatoes grown in Yucatan, Mexico.

The transition temperatures $(\Delta T)$ were 7.41 , 6.11, 7.6 and $8.2^{\circ} \mathrm{C}$ for Colparina, Canchan, Huayro and Yungay, respectively, where at a lower $\Delta T\left(6.11^{\circ} \mathrm{C}\right)$ they required a lower $\Delta \mathrm{H}(11.49 \pm 0.8 \mathrm{~J} / \mathrm{g})$. Similar results have been reiterated by Abegunde et al. (2013), who indicate that variations in starches gelatinization properties could be attributed to several factors, including mineral composition, morphology and size of the granules and molecular structure of starches crystalline region.

\section{Pasting properties}

A paste is a viscous mass, composed of a continuous phase of solubilized amylose and/or amylopectin and a discontinuous phase of ghosts and fragments of granules. Bonding describes changes in starch after heating and gelatinization, increasing swelling and leaching of polysaccharides from the starch granule, resulting in viscosity increasing (Atwell, 1988).

Table 2

Thermal characterization of potato starches

\begin{tabular}{lcccc}
\hline Variety & $\Delta \mathrm{H}(\mathrm{J} / \mathrm{g})$ & $\mathrm{Ti}\left({ }^{\circ} \mathrm{C}\right)$ & $\mathrm{Tp}\left({ }^{\circ} \mathrm{C}\right)$ & $\mathrm{Tf}\left({ }^{\circ} \mathrm{C}\right)$ \\
\hline Colparina & $15.20 \pm 0.34^{\mathrm{a}}$ & $59.67 \pm 0.06^{\mathrm{a}}$ & $62.41 \pm 0.20^{\mathrm{a}}$ & $67.08 \pm 0.12^{\mathrm{a}}$ \\
\hline Canchan & $11.49 \pm 0.8^{\mathrm{b}}$ & $62.23 \pm 0.17^{\mathrm{b}}$ & $64.85 \pm 0.01^{\mathrm{b}}$ & $68.34 \pm 0.29^{\mathrm{b}}$ \\
\hline Huayro & $14.676 \pm 0.55^{\mathrm{a}}$ & $57.90 \pm 0.24 \mathrm{c}$ & $61.18 \pm 0.01^{\mathrm{c}}$ & $65.5 \pm 0.31^{\mathrm{c}}$ \\
\hline Yungay & $15.43 \pm 0.51^{\mathrm{a}}$ & $59.83 \pm 0.11 \mathrm{a}$ & $62.74 \pm 0.19^{\mathrm{a}}$ & $68.03 \pm 0.17^{\mathrm{b}}$ \\
\hline
\end{tabular}

Gelatinization enthalpy $(\Delta H)$, Start temperature (To); Peak temperature (Tp); Final temperature (Tf).

Results are expressed as mean values \pm standard deviation of three determinations. Different letters in the same column indicate significant difference $(p<0.05)$.

Table 3

Pasting properties of potato starches

\begin{tabular}{lccccc}
\hline \multicolumn{1}{c}{ Variety } & $\mathrm{Pt}\left({ }^{\circ} \mathrm{C}\right)$ & $\mathrm{Pv}(\mathrm{cP})$ & $\mathrm{Bd}(\mathrm{cP})$ & $\mathrm{Sb}(\mathrm{cP})$ & $\mathrm{Fv}(\mathrm{cP})$ \\
\hline Colparina & $67.70 \pm 0.23 \mathrm{a}$ & $10135.00 \pm 98.75^{\mathrm{a}}$ & $4198.33 \pm 53.53^{\mathrm{a}}$ & $-193.00 \pm 117.89 \mathrm{a}$ & $5734.67 \pm 147.22 \mathrm{a}$ \\
Huayro & $65.70 \pm 0.31^{\mathrm{a}}$ & $9276.33 \pm 235.10^{\mathrm{b}}$ & $5022.33 \pm 229.31^{\mathrm{b}}$ & $270.67 \pm 178.84 \mathrm{a}$ & $4524.67 \pm 145.14 \mathrm{~b}$ \\
Yungay & $66.15 \pm 0.18^{\mathrm{a}}$ & $10034.00 \pm 106.06^{\mathrm{a}}$ & $5287.67 \pm 123.86^{\mathrm{b}}$ & $-39.33 \pm 136.18^{\mathrm{a}}$ & $4707.00 \pm 126.53^{\mathrm{b}}$ \\
Canchan & $66.52 \pm 0.44^{\mathrm{a}}$ & $8865.00 \pm 238.53^{\mathrm{b}}$ & $3955.00 \pm 241.24 \mathrm{a}$ & $79.67 \pm 305.14 \mathrm{a}$ & $4989.67 \pm 384.81^{\mathrm{ab}}$ \\
\hline
\end{tabular}

Pasting temperatura (Pt); Peak viscosity (Pv); Breakdown (Bd); Setback: (Sb); Final viscosity: (Fv)

Results are expressed as mean values \pm standard deviation of three determinations.

Different letters in the same column indicate significant difference $(p<0.05)$. 
Table 3 shows the starch pasting properties of four potato varieties. The pasting temperature of the starch varied from 65.70 $\pm 0.31{ }^{\circ} \mathrm{C}$ (Huayro) to $67.70 \pm 0.23{ }^{\circ} \mathrm{C}$ (Colparina), without significant difference among varieties $(p>0.05)$. A direct correlation $(91.9 \%)$ was found between this temperature and the enthalpy of gelatinization for Canchan, Huayro and Yungay varieties.

On the other hand, the breakdown viscosity of the starches was higher in the Canchan variety, followed by Colparina, Huayro and Yungay. Jiang et al. (2012) indicate that the breakdown viscosity is the result of the rupture of the swollen granules and is an indicator of the degree of its organization in the starch granule and a tendency to lose viscosity upon holding and shearing. There was an indirect correlation between the amylose content and peak viscosity (98.6\%) for the Colparina, Huayro and Yungay varieties and between the amylose content and final viscosity (99.5\%) for the Huayro, Yungay and Canchan varieties. However, direct correlation (98.9\%) was observed between the amylose content and the setback viscosity for the Colparina, Huayro and Yungay varieties.

Lu et al. (2011) indicate that during the cooling of the starch paste, the leached amylose molecules aggregate rapidly forming binding sites, responsible for the setback and final viscosity. Higher levels of amylose result in a lower peak viscosity and higher setback viscosity in potato starch. The setback viscosity is also related to the rearrangement of amylose molecules that have been leached from the swollen starch granules during cooling, and is generally used as a measurement of the gelling ability or retrogradation tendency of the starch (Karim et al., 2000).

In addition, the maximum viscosity could be related to a higher phosphorus content, which would cause a reduction in the swelling of the starch granules (Chung et al., 2014). At a similar level of amylose, the phosphorus content seems to be an important factor influencing the swelling of potato starches, i.e. potato starches with high phosphorus content tend to give a high maximum viscosity and break their profiles of sticking, but a lower impact on the viscosity recoil is observed. It has also been reported that there is a significant positive correlation between the phosphorus content and the maximum viscosity and the breaking viscosity (Lu et al., 2011). For this reason, it is convenient to carry out phosphorus content studies and analyze the correlation with the sticking properties for the different varieties of potatoes studied.

\section{Rheological Properties - Dynamic measures of viscoelasticity}

The rheological properties of starches separated from five potatoes cultivars during heating are showed in Figure 4 (A, B, C). The predominance of the storage or elastic module ( $\left.G^{\prime}\right)$ on the loss or viscous module (G') can be observed in Figure 4B, which would classify the starch gels as weak gels (Rao, 2014). Martínez et al. (2015) studied the rheological behavior of starch gels from native potatoes, where the G' modules were always greater than the G' modules in oscillatory frequency range (0.1-8 Hz), and showed a slight increase with increase of oscillatory frequency.

A higher elasticity and more rigid structure of the paste are related to higher $G^{\prime}$ and lower $\tan \delta\left(G^{\prime} / G^{\prime}\right)$. During cooling, the decrease in $\tan \delta$ indicates the gel formation, and the increasing $\tan \delta$ during frequency sweep, shows the weakening of gel strength (Li and Zhu, 2017). In the same way it was observed for Colparina, Huayro and Canchan varieties. For Yungay variety, at a frequency $<0.08 \mathrm{~Hz}$, the tan $\delta$ increases (Figure $4 \mathrm{C}$ ). In this case, the gel has elastic behavior (G" > G').

According to Espinosa-Solis and BelloPerez (2009), the higher amylose content provides a higher G'. The results obtained from amylose followed the same trend as the G' modules values for Huayro, Colparina and Canchan varieties. On the other hand, the granule size is another factor that influences the values of the G' module, which at a smaller size of starch gel granule, the values of 'G' module is lower (Li et al., 2017). In the case of the Yungay variety, it contains smaller granule size and its ' ' module is the smallest. Finally, other factors such as granule morphology, relative crystallinity, amylose and amylopectin contend, and traces of others components influences the dynamic rheology of starch ( $\mathrm{Li}$ and Zhu, 2017).

All of the native starch pastes showed pseudoplastic behaviors (Figure 4D) which were described by both Power Law and Herschel-Bulkley equations with high coefficients of determination ( $\left.R^{2}\right)$ (Table 4).

The Herschel-Bulkley model gave a higher $\mathbf{R}^{2}$ due to the presence of the yield stress component in the equation.

The flow behaviors of starch pastes among the four potatoes varieties were different (Table 4). For example, Huayro had the highest $k\left(20.8 \pm 7.2\right.$ Pas $\left.^{n}\right)$ and lowest to (2.2 Pa), while Canchán had the highest $n$ 
$(0.507 \pm 0.006)$ and lowest $k(6.0 \pm 0.8)$. The differences could be attributed to various factors such as granule morphology, relative crystallinity, amylose and amylopectin content, and traces of others components (Li et al., 2017). Amylose content is responsible for the initial paste formation (Kong et al., 2010), and the somewhat amylose content lower may explain the lower yield stress. However, the different starches of potatoes varieties do not have significant difference $(p>0.05)$ in yield stress $\left(T_{0}\right)$, having values close to zero and fitting to Ostwald-De Weale model.

In virtue of that functional properties shown by the starches of 4 commercial potatoes, this work look for the revaluation of this potatoes varieties. In particular, the high amylose content, the physicochemical properties and thermal properties found from the studied starches, could be used as additive in several foods preparation.

Ayucitra (2012) states that gels clarity is a property to take into account for manufac-
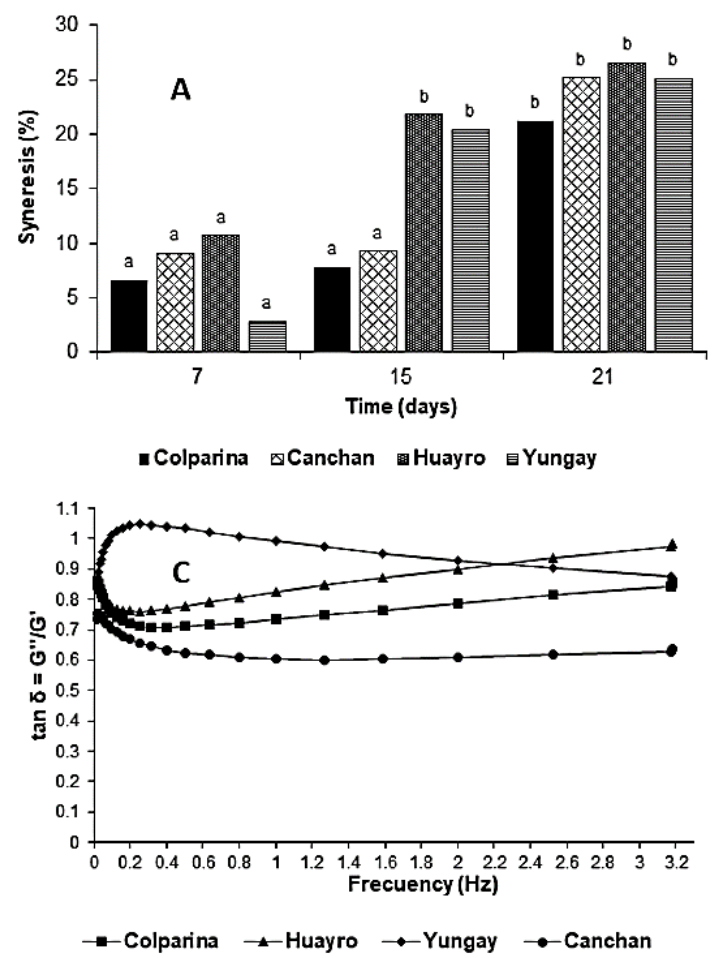

ture some food products such as salad dressings and foods such as jams, gelatins, and in confectionery for making gummies. Therefore, Colparina and Canchan starches, due to their high percentage transmittance, could be used for this purpose; while Huayro and Yungay starches could be used in non-transparent foods, such as mayonnaises, meat products, nectar-type concentrated beverages or bakery products.

According to its thermal properties, Canchan starch, due to its high gelatinization temperature, could be used in products that require high temperatures, such as canned products, baby food, and so on. Regarding viscosity, as stated by Aprianita et al. (2009), the high viscosity starches could be potentially useful for applications in the food industry where increasing the thickening power is desirable. In this way, Colparina and Yungay starches could be used for this purpose.
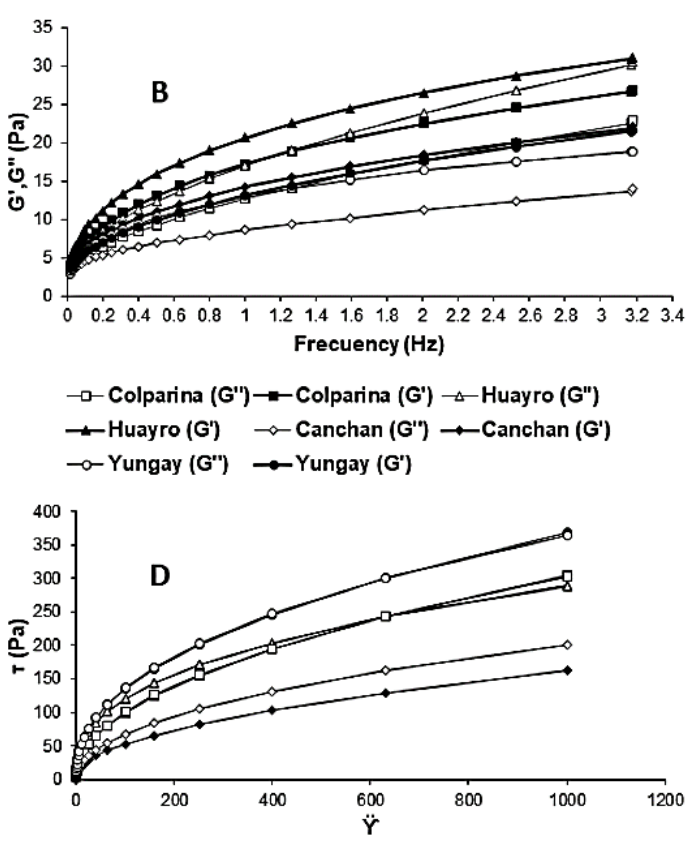

$$
\begin{aligned}
& \leftarrow \text { HB-Huayro } \rightarrow \text { HB-Colparina } \rightarrow \text { HB-Canchan } \\
& \rightarrow \text {-HB-Yungay } \rightarrow-\text { LP-Huayro } \rightarrow \text {-LP-Colparina } \\
& \diamond \text {-LP-Canchan } \rightarrow \text {-LP-Yungay }
\end{aligned}
$$

Figure 4. Syneresis $(\%)$ of potato starch gels in refrigeration $\left(4^{\circ} \mathrm{C}\right)(\mathrm{A})$. Frequency sweep of modulus $\mathrm{G}^{\prime}$ and modulus $G$ " of potato starch gels (B). Relationship of $\tan \delta$ (G"/G') with frequency sweep of potato starch gels (C). Power Law and Herschel-Bulkley models (D). Different letters during storage days indicate significant difference $(p<0.05)$.

Table 4

Steady shear properties of starch pastes modelled by Power Law and Herschel-Bulkley equations

\begin{tabular}{lccccccc}
\hline \multirow{2}{*}{ Starch } & \multicolumn{2}{c}{ Power Law (Ostwald-De Weale) } & \multicolumn{4}{c}{ Herschel - Bulkley } \\
& $k\left(\operatorname{Pas}^{n}\right)$ & $\eta$ & $R^{2}$ & $T$ o $(\mathrm{Pa})$ & $k\left(\mathrm{Pas}^{n}\right)$ & $\eta$ & $\mathbf{R}^{2}$ \\
\hline Colparina & $11.200 \pm 2.484^{\mathrm{a}}$ & $0.479 \pm 0.018 \mathrm{a}$ & 0.9996 & $4.124 \pm 0.650^{\mathrm{a}}$ & $9.551 \pm 2.438 \mathrm{a}$ & $0.50 \pm 0.023 \mathrm{a}$ & 0.999 \\
Huayro & $21.865 \pm 5.668 \mathrm{~b}$ & $0.371 \pm 0.088^{\mathrm{a}}$ & 0.9988 & $2.175 \pm 3.767 \mathrm{a}$ & $20.825 \pm 7.235^{\mathrm{b}}$ & $0.381 \pm 0.099 \mathrm{a}$ & 0.998 \\
Canchan & $7.714 \pm 1.135^{\mathrm{a}}$ & $0.473 \pm 0.014 \mathrm{a}$ & 0.9990 & $4.141 \pm 1.568 \mathrm{a}$ & $6.024 \pm 0.842 \mathrm{a}$ & $0.50 \pm 0.006 \mathrm{a}$ & 0.999 \\
Yungay & $19.428 \pm 0.396^{\mathrm{b}}$ & $0.425 \pm 0.007 \mathrm{a}$ & 0.9990 & $5.536 \pm 4.000^{\mathrm{a}}$ & $16.653 \pm 2.701^{\mathrm{b}}$ & $0.45 \pm 0.016^{\mathrm{a}}$ & 0.999 \\
\hline
\end{tabular}

$k$, consistency coefficient; $\eta$, flow behaviour index; To, yield stress; $R^{2}$, coefficient of determination. Different letters in the same column indicate significant difference $(p<0.05)$. 


\section{Conclusions}

The evaluated potato starches showed significant variations $(p<0.05)$ in physicochemical, thermal and pasting properties, which make them feasible for using in various food systems or other industrial applications. Low syneresis percentage presented by the starch gel from Colparina variety can be used as stabilizer or gelling agent in refrigerated foods, and due to its high clarity, this can be used for cakes and sweets production. Canchan potato starch, due to its high gelatinization temperature $\left(62.23 \pm 0.17^{\circ} \mathrm{C}\right)$, can be used in products that require high temperatures, such as canned products or baby food. The starches presented typical rheological behavior, as well as the viscoelastic behavior, with greater predominance of elastic behavior (G'> G'). Starch gels of the Yungay and Huayro varieties had a higher consistency index, which is related to their high amylose content and a greater average grain size. Finally, the variability and relationships observed among the studied starches characteristics will be potentially useful to determine specific uses in food and nonfood applications. Therefore, giving an added value for the commercialization of these potatoes.

\section{Acknowledgments}

The authors are grateful to:

- The Innovate Peru for funding the project $N^{\circ} 121$ FINCYT-ECL-2014.

- The Laboratório de Engenharia de Processos (Ge'2PESALQ/USP) for the support and facilities of RVA analysis, especially to Pedro Esteves Duarte Augusto $\mathrm{PhD}$ and Alberto Claudio Miano Pastor Ms.

- The Multidisciplinary Research Laboratory of Universidad Privada Antenor Orrego for the support and facilities of Electron Microscopy and X-ray analysis, in the name of Manuel Angelats PhD and Henry León Ms.

- The Laboratorio de Ingeniería de Procesos for the support and facilities of rheological analysis, especially to Raúl Siche Jara PhD.

\section{ORCID}

J.A. Sanchez-González (iD https://orcid.org/0000-0002-9264-6268 L. Lescano (iD https://orcid.org/0000-0002-7359-1134

H.L. Linares (iD https://orcid.org/0000-0003-3889-4831

H.L. Arteaga-Miñano (D) https://orcid.org/0000-0003-1425-3757

G. Barraza-Jáuregui (iD https://orcid.org/0000-0002-0376-2751

\section{References}

Abegunde, O.K.; Mu, T.-H.; Chen, J.-W.; Deng, F.-M. 2013. Physicochemical characterization of sweet potato starches popularly used in Chinese starch industry. Food Hydrocolloids 33(2): 169-177.

Aprianita, A.; Purwandari, U.; Watson, B.; Vasiljevic, T. 2009. Physico-chemical properties of flours and starches from selected commercial tubers available in Australia. International Food Research Journal 16(4): 507-520.

Aristizábal, J.; Sánchez, T.; Lorío, D.M. 2007. Guía técnica para producción y análisis de almidón de yuca: Organización de las Naciones Unidas para la Agricultura y la Alimentación Roma.

Atwell, W. 1988. The terminology and methodology associated with basic starch phenomena. Cereal foods world 33: 306-311.

Ayucitra, A. 2012. Preparation and characterisation of acetylated corn starches. International Journal of Chemical Engineering Applications 3(3): 156.

Berski, W.; Ptaszek, A.; Ptaszek, P.; Ziobro, R.; Kowalski, G.; Grzesik, M.; Achremowicz, B.J.C.P. 2011. Pasting and rheological properties of oat starch and its derivatives 83(2): 665-671.

Chung, H.-J.; Li, X.-Q.; Kalinga, D.; Lim, S.-T.; Yada, R.; Liu, Q. 2014. Physicochemical properties of dry matter and isolated starch from potatoes grown in different locations in Canada. Food research international 57: 89-94.

CIP. 2018. Datos y Cifras de la Papa, from https://cipotato.org/es/potato/potato-facts-andfigures/

Espinosa-Solis, V.; Jane, J.I.; Bello-Perez, L.A. 2009. Physicochemical characteristics of starches from unripe fruits of mango and banana. Starch-Stärke 61(5): 291-299.

Gomand, S.; Lamberts, L.; Derde, L.; Goesaert, H.; Vandeputte, G.; Goderis, B.; Delcour, J. 2010. Structural properties and gelatinisation characteristics of potato and cassava starches and mutants thereof. Food hydrocolloids (4): 307-317.

Grommers, H.E.; van der Krogt, D.A. 2009. Potato starch: production, modifications and uses. Starch (Third Edition): 511-539.

Hernández-Medina, M.; Torruco-Uco, J.G.; ChelGuerrero, L.; Betancur-Ancona, D. 2008. Caracterización fisicoquímica de almidones de tubérculos cultivados en Yucatán, México. Food Science and Technology 28(3): 718-726.

INEI. 2017. Producción de papa aumentó $9,0 \%$ en julio de 2017 Retrieved 09/01/2018, 2018, from https://www.inei.gob.pe/prensa/noticias/produccion -de-papa-aumento-90-en-julio-de-2017-9976/

Jiang, Q.; Gao, W.; Li, X.; Xia, Y.; Wang, H.; Wu, S.; Xiao, P. 2012. Characterizations of starches isolated from five different Dioscorea L. species. Food Hydrocolloids 29(1): 35-41.

Joshi, M.; Aldred, P.; McKnight, S.; Panozzo, J.; Kasapis, S.; Adhikari, R.; Adhikari, B.J.C.P. 2013. Physicochemical and functional characteristics of lentil starch 92(2): 1484-1496.

Karim, A.A.; Norziah, M.H.; Seow, C.C. 2000. Methods for the study of starch retrogradation. Food Chemistry 71(1): 9-36.

Kaur, A.; Singh, N.; Ezekiel, R.; Guraya, H.S. 2007. Physicochemical, thermal and pasting properties of starches separated from different potato cultivars grown at different locations. Food Chemistry 101(2): 643-651.

Kaur, A.; Singh, N.; Ezekiel, R.; Sodhi, N.S. 2009. Properties of starches separated from potatoes stored under different conditions. Food Chemistry 114(4): 1396-1404.

Kong, X.; Kasapis, S.; Bertoft, E.; Corke, H. 2010. Rheological properties of starches from grain amaranth and their relationship to starch structure. Starch-Stärke 62(6): 302-308.

Li, D.; Yang, N.; Jin, Y.; Guo, L.; Zhou, Y.; Xie, Z.; Xu, X. 2017. Continuous-flow electro-assisted acid hydrolysis of granular potato starch via inductive methodology. Food chemistry 229: 57-65.

Li, D.; Zhu, F.J.F.C. 2017. Physicochemical properties of kiwifruit starch. Food Chemistry 220: 129-136.

Lin, J.-H.; Kao, W.-T.; Tsai, Y.-C.; Chang, Y.-H. 2013. Effect of granular characteristics on pasting properties of starch blends. Carbohydrate polymers 98(2): 1553-1560.

Liu, Q.; Weber, E.; Currie, V.; Yada, R. 2003. Physicochemical properties of starches during potato growth. Carbohydrate Polymers 51(2): 213221. 
Lu, S.; Chen, J.J.; Chen, Y.K.; Lii, C.Y.; Lai, P.; Chen, H. H. 2011. Water mobility, rheological and textural properties of rice starch gel. Journal of Cereal Science 53(1): 31-36

Martínez, P.; Málaga, A.; Betalleluz, I.; Ibarz, A.; Velezmoro, C. 2015. Caracterización funcional de almidones nativos obtenidos de papas (Solanum phureja) nativas peruanas. Scientia Agropecuaria 6(4): 291-301.

Medina, J.A.; Salas, J.C. 2008. Caracterización morfológica del granulo de almidón nativo: Apariencia, forma, tamaño y su distribución. Revista de ingeniería 27: 56-62.

Noda, T.; Tsuda, S.; Mori, M.; Takigawa, S.; MatsuuraEndo, C.; Saito, K.; Yamauchi, H. 2004. The effect of harvest dates on the starch properties of various potato cultivars. Food chemistry 86(1): 119-125.

Novelo-Cen, L.; Betancur-Ancona, D. 2005. Chemical and functional properties of Phaseolus lunatus and Manihot esculenta starch blends. Starch-Stärke 57(9): 431-441.

Rao, M.A. 2014. Flow and functional models for rheological properties of fluid foods Rheology of Fluid, Semisolid, and Solid Foods (pp. 27-61): Springer.
Šimková, D.; Lachman, J.; Hamouz, K.; Vokál, B. 2013. Effect of cultivar, location and year on total starch, amylose, phosphorus content and starch grain size of high starch potato cultivars for food and industrial processing. Food chemistry 141(4): 3872 3880.

Singh, J.; McCarthy, O.J.; Singh, H. 2006. Physicochemical and morphological characteristics of New Zealand Taewa (Maori potato) starches. Carbohydrate polymers 64(4): 569-581.

Singh, N.; Singh, J.; Kaur, L.; Sodhi, N.S.; Gill, B.S. 2003. Morphological, thermal and rheological properties of starches from different botanical sources. Food Chemistry 81(2): 219-231.

Torruco-Uco, J.; Betancur-Ancona, D. 2007. Physicochemical and functional properties of makal (Xanthosoma yucatanensis) starch. Food Chemistry 101(4): 1319-1326.

Wang, L.; Xie, B.; Shi, J.; Xue, S.; Deng, Q.; Wei, Y.; Tian, B. 2010. Physicochemical properties and structure of starches from Chinese rice cultivars. Food Hydrocolloids 24(2-3): 208-216. 